\title{
THE THEORY OF Human CAPITAL REVISITED: ON THE INTERACTION OF GENERAL AND SPECIFIC INVESTMENTS
}

\author{
ANKE S. KESSLER \\ CHRISTOPH LÜLFESMANN
}

CESIFO WORKING PAPER NO. 776

CATEGORY 4: LABOUR MARKETS

SEPTEMBER 2002

Presented at CESifo Venice Summer Institute, July 2002

An electronic version of the paper may be downloaded

- from the SSRN website: www.SSRN.com

- from the CESifo website: www.CESifo.de 


\title{
THE THEORY OF HUMAN CAPITAL REVISITED: ON THE INTERACTION OF GENERAL AND SPECIFIC INVESTMENTS
}

\begin{abstract}
Human capital theory distinguishes between training in general-usage and firm-specific skills. In his seminal work, Becker (1964) argues that employers will not be willing to invest in general training when labor markets are competitive. However, they are willing to invest in specific training because it cannot be transferred to outside firms. The paper reconsiders Becker's theory. We show that there exists an incentive complementarity between employersponsored general and specific investments: the possibility to provide specific training leads the employer to invest in general human capital. Conversely, the latter reduces the hold-up problem that arises with respect to the provision of firm-specific training. We also consider the virtues of long-term contracting and discuss some empirical observations that could be explained by the model.
\end{abstract}

JEL Classification: C78, L14, L15, D82.

Keywords: human capital formation, general and specific training, hold-up problem.

\author{
Anke S. Kessler \\ University of Bonn \\ Department of Economics \\ Adenauerallee 24-42 \\ 53113 Bonn \\ Germany \\ kessler@wipol.uni-bonn.de
}

\author{
Christoph Lülfesmann \\ University of Bonn \\ Department of Economics \\ Adenauerallee 24-42 \\ 53113 Bonn \\ Germany \\ clmann@wiwi.uni-bonn.de
}

The first draft of this paper was written when both authors visited the Haas School of Business at UC Berkeley in 1998/99. We are indebted to Jim Malcomson, Holger Müller, Hessel Oesterbeck, Steve Pischke, Stefan Reichelstein, Monika Schnitzer, Klaus Schmidt, $\mathrm{Kuo} \mathrm{Yu}$, as well as various seminar participants at the Universities of Bonn, Munich and Amsterdam, the Simon Fraser University, and the ESSET 2000 meeting in Gerzensee for helpful discussions. Special thanks belong to George Baker, Ed Lazear and David Levine for their encouraging comments. Both authors gratefully acknowledge that their research was partially financed by the Deutsche Forschungsgemeinschaft, SFB 303 at the University of Bonn. We also thank the Haas School of Business for its hospitality and the DAAD for financial support. Remaining errors are our own. 


\section{Introduction}

Based on the transferability of the acquired skills, human capital theory distinguishes between investments in general-usage and specific human capital. As pointed out by Becker (1964), this distinction is important if these investments take the form of employer-provided training. While the returns to specific training can be realized only in an ongoing relationship with the training firm, general training increases the productivity of a worker in many firms besides those providing it. Becker's theory separately addresses these phenomena and draws two main conclusions. First, employers will share the returns and the cost of investments in firm-specific skills with their employees. Second, in a competitive labor market firms will not invest into general skills of their employees due to their inability to collect the returns from such investments. Therefore, workers will pay the full cost of general training.

Yet, there is a range of evidence indicating that firms voluntarily bear the cost of training, even if the acquired skills are largely general in nature. This is particularly apparent in countries with institutionalized apprenticeship systems. In Germany, for example, participants in the system (secondary school graduates) engage in part-time schooling and on-the-job training and receive upon completion a nation-wide accepted certificate that helps to make their skills marketable throughout the profession. Franz and Soskice (1995) estimate that German employers paid a net cost per apprentice of about DM 12.300 in 1985. Using 1991 survey data on training firms in Germany, von Bardeleben, Beicht and Feher (1995) conclude that even under the most conservative assumptions, the net cost of an apprentice in a larger German firm exceeds DM 7.500. ${ }^{1}$

The present paper reconsiders Becker's seminal arguments in a framework where firms can provide both general and specific training. To this end, we employ a simple model that preserves two essential characteristics of the standard theory: a) the labor market is frictionless in the sense that a worker always receives the full return from general training and b) he obtains a share of the return from specific training. Our main result is that employers may still voluntarily provide a positive amount of general training or, alternatively, be willing to share the costs of such training with their employees. As a first step to this conclusion, we find that general and specific investments cannot

\footnotetext{
${ }^{1}$ Interestingly, this study also estimates net training costs to be negative for small firms (see Section 3 for a discussion). For further evidence on firm-sponsored general training, see Soskice (1994) and Harhoff and Kane (1997) for Germany, and Ryan (1980) and Bishop (1991) for the U.S.
} 
be separately analyzed. Rather, the presence of the relationship-specific rent that is generated through firm-specific training makes the parties' returns from either type of investment interdependent even if (as we posit) there is no technological link between them. The idea of our approach can be outlined as follows. If a firm can provide only general training, it has no incentives to invest since the employee can recover the full return on his human capital in the absence of market imperfections. If, in contrast, the firm can also expend investments in relationship-specific skills, this will create a wedge between the worker's productivity if he leaves his current employer and his productivity if employment continues beyond the training period. Once training is completed, firm and worker are therefore in a bilateral monopoly position.

Now suppose for example that in the ensuing wage negotiations, the surplus from continued employment is divided with the external market opportunities acting as outside options. Then, although the (above market) rent depends only on the worker's specific human capital, the way in which it is shared also depends on his general skills. In particular, as long as the external market opportunity of the worker (which fully reflects his marginal product from general training) is binding, negotiations will lead to the going market wage. As a result, the rent from specific human capital accrues entirely to the firm while it appropriates no return from the worker's general human capital. If this rent is sufficiently large relative to the return on general human capital, however, or if the worker's bargaining power is sufficiently high, his share of the surplus from continued employment will be above what he can realize on the external market. As a consequence, the worker captures part of the rent from specific skills and a 'Hold-up' problem [Williamson (1985), Grout (1984)] arises. While hold-up discourages specific training, it at the same time improves the firm's incentives to provide general training: although external wages rise one-to-one with a worker's productivity from general skills, the wage he obtains if he stays with the training firm rises by less than that if surplus sharing (hold-up) occurs.

A number of results follow immediately from this observation. First, the higher the level of specific training, the larger the resulting gap and, hence, the more incentives the firm has to to invest into general training. Second, the reverse also holds, i.e., general skills enhance the firm's provision of specific training relative to a scenario where general training is not taken into consideration. This is because in situations where a worker's outside wage is binding for given investment levels, the employer reaps the full return from specific investments on the margin because each worker's equilibrium wage 
then coincides with his marginal product from general training. As a consequence, her investment incentives in specific training increase as compared to a setting without general training where the worker's outside wage poses a weaker constraint in bargaining. Hence, general and specific human capital are complementary from the firm's point of view even if their returns (and provision costs) are technologically disconnected. For this reason, we also find that the parties will agree on a general training level in excess of the first best if this investment can be contracted upon in advance. Since general and specific training are complements, a higher level of general training stimulates the provision of specific investments, and thus further alleviates the hold-up problem that arises when specific training is non-contractible. Finally, we argue that extending our framework to allow for (equilibrium) turnover, the possibility of long-term contractual arrangements, or more general bargaining solutions qualitatively leaves these conclusions unaffected.

The present paper is related to several contributions in the literature. First, we adopt our theoretical approach from previous work on specific investments and the hold-up problem. ${ }^{2}$ In particular, our analysis draws on MacLeod and Malcomson (1993a, 1995) who provide a natural framework to study both general and specific investments in bilateral trade relationships. To formalize how the rent generated through specific investments is shared among the parties, the authors develop a bargaining game where negotiation and trade takes place over time, which reflects the long-term nature of employment relationships well. The equilibrium outcome follows the outside option principle, which we adopt for analytical simplicity. ${ }^{3}$ As we will see below, however, this solution is not necessary for our findings. MacLeod and Malcomson (1993a, 1993b) use this model to investigate under which conditions simple contractual arrangements can induce efficient investments. In particular, it is shown that a long-term contract which specifies a fixed price (wage) and possibly in addition a fee paid in case of termination (a redundancy payment) will induce one party to expend efficient specific investments, even if those also benefit the other party as is the case with firm-sponsored specific training. They do not consider a situation where the firm provides general training, which is the focus of our analysis. ${ }^{4}$

\footnotetext{
${ }^{2}$ See among others, Grout (1984), Grossman and Hart (1986), Hart and Moore (1990) and Edlin and Reichelstein (1996).

${ }^{3}$ This principle has been derived in a version of the Rubinstein game where at least one party can take an outside option [Shaked and Sutton (1984)] and states that outside options act as a lower bound to a party's payoffs in negotiations but otherwise do not affect the outcome.

${ }^{4}$ MacLeod and Malcomson (1993a) also study general investments by both agents but these are
} 
Second, a number of recent papers analyze human capital accumulation in the context of employment relationships and propose several reasons for why we observe firmsponsored general training. This literature mainly focuses on general training and disregards specific investments. One prominent explanation is based on asymmetric information between the training firm and potential future employees. Katz and Ziderman (1990) suggest that the firm may be willing to invest in a worker's general skills if his level of training is unobserved by the market. ${ }^{5}$ Acemoglu and Pischke (1998) study a model where the training firm obtains superior information on the worker's ability during the training period. The informational disadvantage of firms in the external labor market gives rise to adverse selection, i.e., the equilibrium market wage falls short of the marginal product of highly skilled workers. As a result, a training firm enjoys some monopsony power over its workers and is able to capture (part of) the return from general training. A similar situation arises if general skills are only valuable in a small number of firms [Stevens (1994), Gersbach and Schmutzler (2001)] or if there are search costs associated with finding alternative employers [Acemoglu (1997)]. Acemoglu and Pischke (1999) motivate the prevalence of employer-financed general training by the existence of market frictions that compress the structure of wages in the sense that the outside wage falls short of the marginal product from general skills and this wedge increases in the level of training provided. The authors show that such wage compression can endogenously emerge in economies with minimum wages, wage-setting unions, or worker moral hazard. Finally, they note that firm-sponsored investments in general training is encouraged if general and specific skills are complements in a firm's production function. A related argument has been put forward by Franz and Soskice (1995) who recognize that employers may provide general training if general and specific investments are complements in the firm's investment cost function.

The remainder of the paper proceeds as follows. Section 2.1 develops the basic model with general and specific investments which is analyzed in Section 2.2. The following Section 2.3. briefly considers the implications of labor turnover and the possibility of long-term contracting. In Section 3 we discuss our results and their implications and relate them to empirical evidence. A final Section 4 concludes.

'selfish' in the sense that they do not affect the external market opportunity of the other party.

${ }^{5}$ See also Chiang and Chiang (1990) and Chang and Wang (1996). 


\section{A Model of General and Specific Training}

\subsection{The Basic Framework}

Consider the following simple model of human capital accumulation in the labor market. There are two risk-neutral parties: a worker and a firm operating in a competitive labor market. ${ }^{6}$ Time is divided into a training period $t=1$ and a subsequent employment period $t=2$ and there is no discounting. In period $t$, the worker produces an output of $v_{t}$, measured in monetary terms, and receives a wage $w_{t}$. Without loss of generality, we normalize his disutility from work to zero. In the first period, the worker is unskilled but may be trained by the firm in both general and firm-specific skills. The firm's total outlays for general and specific training are denoted by $g \in[0, \bar{g}] \subset \mathbb{R}$ and $s \in[0, \bar{s}] \subset \mathbb{R}$, respectively. Throughout the analysis, we assume that the amount of specific on-the-job training $s$ cannot be contractually specified. Training in general skills $g$, in contrast, may or may not be contractible, depending for example on whether there is a formal apprenticeship program in which the parties participate or not.

For simplicity, we let the productivity of an unskilled worker in $t=1$ be independent of the amount of training he receives and be equal to $v_{1}=\underline{v}_{1} \geq 0$. The output $v_{2}$ of a skilled worker in $t=2$ is determined by the firm's investments in general and specific training, $g$ and $s$, as well as a random parameter $\theta$ which may be interpreted as the worker's ability or as an industry-wide shock that affects market conditions. $\theta$ becomes known to both parties after the first period and is distributed according to a continuously differentiable distribution function $F(\theta)$ over a bounded support $[\underline{\theta}, \bar{\theta}]$. Let $\sigma=(s, g, \theta) \in \Sigma$ be the state of the world in $t=2$. To make our point as strong as possible, we disregard in what follows the possibility of technological complementarities between general and specific training. Thus, the productivity of a skilled worker is additively separable in $g$ and $s$,

$$
v_{2}(s, g, \theta)=v^{S}(s, \theta)+v^{G}(g, \theta), \quad \forall \sigma \in \Sigma
$$

where $v^{S}$ and $v^{G}$ are the components of $v_{2}$ that can be attributed to the acquisition of firm specific and general skills, respectively.

\footnotetext{
${ }^{6}$ Restricting attention to a single worker-firm pair is done for expositional convenience only and inconsequential for the results that follow. It is formally justified if there is a sufficiently large number of firms in the market and all firms have access to the same technology that is linear in the number of workers they employ. Risk-neutrality helps us to abstract from insurance considerations that would unnecessarily complicate the analysis [see Rosen (1994) for a survey on this issue].
} 
Assumption 1. The function $v_{2}(\cdot)$ is continuously differentiable, strictly concave and increasing in $(s, g)$. Furthermore, for all $\sigma \in \Sigma$,

a) $\lim _{i \rightarrow 0} \partial v_{2}(s, g, \theta) / \partial i=\infty$ and $\lim _{i \rightarrow \bar{i}} \partial v_{2}(s, g, \theta) / \partial i=0, \quad i \in\{s, g\}$,

b) $\inf _{\sigma} v_{2}(s, g, \theta)=\underline{v}_{2} \geq 0$ and $v_{2}(0, g, \theta)=v^{G}(g, \theta)$.

Part a) of Assumption 1 implies that it is always socially optimal to have a positive amount of either type of training. Part b) ensures that subsequent employment (whether with the current employer or with another firm on the external labor market) is always efficient. Moreover, in the absence of specific investments, all productivity is general in nature. Given the state $\sigma$ at the beginning of period 2, worker and firm negotiate on the second-period wage in a way to be detailed below. Both parties are free to terminate their relationship at that time, i.e., the worker may decide to quit or the firm may decide to lay the worker off. In either case, the parties have access to the external labor market. The wage determined in this market is denoted by $w^{E}$. By definition, the worker's general skills are perfectly marketable while his specific skills loose their value in case of a separation. Thus, another firm hiring the worker (or the firm hiring another skilled worker) would value his output at $v^{G}(g, \theta)$.

Assumption 2. There is perfect competition on the external labor market in both periods and the state $\sigma=(s, g, \theta)$ is commonly observable. Hence, $w^{E}=v^{G}(g, \theta)$ for all $\sigma \in \Sigma$.

The sequence of events is summarized in Figure 1. In stage 0, the firm offers a wage contract $w_{1}$ to the worker that governs the training period. If feasible, the contract may also specify how much training in general skills $g$ he is to receive. Once hired the worker produces $\underline{v}_{1}$, and the firm decides in stage 1 on training outlays $s$ and $g$. In stage 2 , first period payoffs $\pi_{1}=\underline{v}_{1}-w_{1}-s-g$ and $u_{1}=w_{1}$ are realized. The random parameter $\theta$ (e.g., the worker's ability) becomes known in stage 3. The second-period wage $w_{2}$ is negotiated in stage 4 . If employment continues, the worker produces $v_{2}$ and the parties' second-period payoffs are $\pi_{2}=v_{2}-w_{2}$ and $u_{2}=w_{2}$. If the relationship is terminated, either party can take up its external market opportunity. The payoffs in this case are denoted by $u^{E}$ and $\pi^{E}$, respectively.

For future reference, let us briefly calculate the efficient levels of training. To this end, recall that by Assumption 1, the worker should be hired in $t=1$ and continued to 


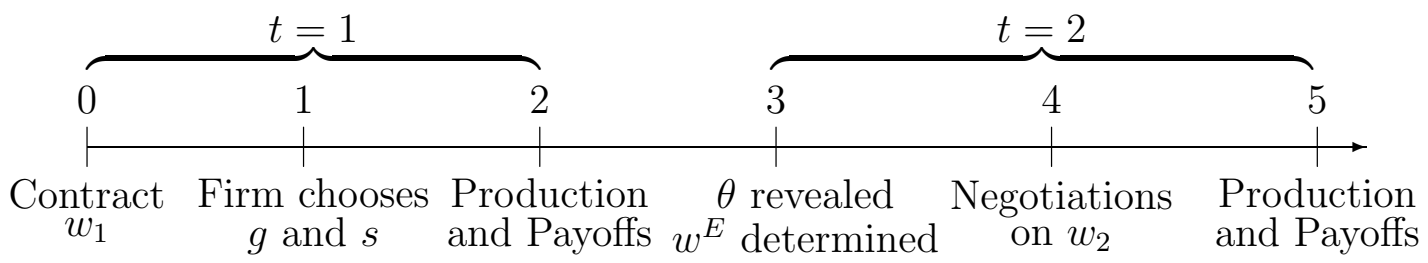

Figure 1: Sequence of Events

be employed by the firm in $t=2$, irrespective of its training outlays $s$ and $g{ }^{7}$ The first-best amount of training each worker receives is thus uniquely defined by

$$
\left(s^{F B}, g^{F B}\right)=\arg \max _{(s, g) \geq 0} \int_{\theta \in[\underline{\theta}, \bar{\theta}]}\left[v_{2}(s, g, \theta)\right] d F(\theta)+\underline{v}_{1}-s-g .
$$

Using (1), the corresponding first-order conditions are

$$
\begin{aligned}
\int_{\theta \in[\underline{\theta}, \bar{\theta}]} \frac{\partial v^{S}\left(s^{F B}, \theta\right)}{\partial s} d F(\theta) & =1, \\
\int_{\theta \in[\underline{\theta}, \bar{\theta}]} \frac{\partial v^{G}\left(g^{F B}, \theta\right)}{\partial g} d F(\theta) & =1,
\end{aligned}
$$

equating the expected marginal return from each type of training with its marginal cost. As one would expect, $g^{F B}$ and $s^{F B}$ are determined independently from each other due to the separability of $v_{2}(\cdot)$.

It remains to describe the outcome of the negotiations between the firm and a worker on the second-period wage $w_{2}$. Recall that those take place under symmetric information since the state is known to both parties in stage 4. Clearly, if an agreement is reached and the relationship continues, the net surplus to be divided in negotiations is equal to second period net production $v_{2} \geq 0$. However, each party can terminate the relationship and take up its external market opportunity in which case the payoff to the firm and the worker is $\pi^{E}$ and $u^{E}$, respectively. In the subsequent formal analysis, we assume for concreteness that negotiations can be formalized by a bargaining solution which ensures efficiency and is characterized by the outside option principle. How our results generalize to other bargaining solutions is discussed in Section 3 below.

\footnotetext{
${ }^{7}$ The assumption that the worker should always stay with the training firm will be relaxed in Section 2.3. below which addresses the possibility of efficient separation in $t=2$.
} 
Assumption 3. Let $\alpha \in(0,1)$ be a parameter that measures the relative bargaining power of the worker. The second period equilibrium payoffs $\pi_{2}^{*}$ and $u_{2}^{*}$ in the negotiation game are unique and satisfy $\pi_{2}^{*}+u_{2}^{*}=v_{2}(s, g, \theta), \forall \sigma \in \Sigma$ where

$$
\begin{aligned}
u_{2}^{*} & = \begin{cases}\alpha v_{2}(\cdot) & \text { for } \alpha v_{2}(\cdot) \geq u^{E} \\
u^{E} & \text { otherwise, }\end{cases} \\
\text { and } \pi_{2}^{*} & = \begin{cases}(1-\alpha) v_{2}(\cdot) & \text { for }(1-\alpha) v_{2}(\cdot) \geq \pi^{E} \\
\pi^{E} & \text { otherwise. }\end{cases}
\end{aligned}
$$

Thus, worker and firm share the surplus from continued employment according to their relative bargaining power with their external market opportunities acting as an outside option, i.e., they constitute a lower bound on each party's payoff but otherwise do not affect the outcome. This formulation is consistent with several extensive-form bargaining games that have been developed in the context of labor markets [Shaked and Sutton (1984), MacLeod and Malcomson (1993a, 1995)]. ${ }^{8}$ It can further be simplified by noting that $\pi^{E}=0$ because competition on the external labor market ensures that the firm hiring another worker always has to pay him his full marginal product [Assumption 2]. Due to $v_{2}(\cdot) \geq 0$ [Assumption 1], the firm's share of the surplus from continued employment always weakly exceeds the profit from taking up its external market opportunity. We can thus disregard the firm's outside option in what follows and characterize the negotiation outcome in terms of the second period equilibrium wage $w_{2}^{*}$ which, using $u_{2}=w_{2}-c$ and $u^{E}=w^{E}-c$, is given by

$$
w_{2}^{*}= \begin{cases}\alpha v_{2}(\cdot) & \text { for } \alpha v_{2}(\cdot) \geq w^{E} \\ w^{E} & \text { otherwise. }\end{cases}
$$

Two characteristics of $w_{2}^{*}$ are notable. First, the employee always receives at least his marginal product from general skills, $w^{E}=v^{G}(g, \theta)$. Second, if the worker prefers his equilibrium wage in the absence of an outside opportunity to the wage he can obtain in the external labor market, the latter does not influence the bargaining outcome

\footnotetext{
${ }^{8}$ More specifically, the unique subgame perfect equilibrium of the game studied by Shaked and Sutton (which is based on the Rubinstein bargaining game) coincides in the limit were discounting is negligible with the outcome in Assumption 3 for $\alpha=1 / 2$. Arbitrary values of $\alpha$ can be introduced into the alternating-offers game by assuming that nature chooses which player makes an offer in each bargaining round with constant probability [see Binmore (1987)]. Using this variant of the Rubinstein game, MacLeod and Malcomson (1993a, 1995) develop a model of contract (re-)negotiation where trade occurs over time rather than at a single date, thus reflecting the long-term nature of employment relationships very well. Under our specification (and assuming that the worker strictly prefers not to work in the absence of a contract, i.e., a zero wage), the unique subgame perfect equilibrium in their model if the time interval between offers vanishes again coincides with the outcome in Assumption 3.
} 
(outside option principle). As the literature on non-cooperative bargaining has shown, this property will prevail if a quit (or layoff) effectively terminates the negotiations and forgoes all future gains from cooperation so that the worker cannot credibly threaten to quit in such a situation. ${ }^{9}$

\section{General Investments in Human Capital}

Let us first investigate a situation where the firm cannot or does not invest into relationship specific skills of the worker by setting $s \equiv 0$. Because all training is then general, the employee is as valuable inside the existing relationship as on the external labor market. Hence, competition among firms ensures that the worker is paid his full marginal product $v^{G}(g, \theta)$, irrespective of whether the relationship is continued or the worker seeks outside employment. By (4), negotiations will lead to a second-period wage of $w_{2}^{*}=w^{E}$ : surplus sharing never occurs simply because there is no rent in excess of what can be obtained in the market. The firm's second period profit is thus $\pi_{2}^{*}=0$ and the worker's utility is $u_{2}^{*}=v_{2}(0, g, \theta)=v^{G}(g, \theta)$. The expected overall returns from the relationship are then given by $E[\pi(0, g)]=\underline{v}_{1}-w_{1}-g$ and $E[u(0, g)]=w_{1}+E_{\theta}\left[v^{G}(g, \theta)\right]$, respectively. The following proposition is immediate and replicates Becker's (1964) seminal argument.

Proposition 1. Suppose the firm does not invest into specific skills of the employee, i.e., $s \equiv 0$. Then, the equilibrium level of general training $g^{*}$ and the first period wage $w_{1}^{*}$ satisfy

a) $g^{*}=0$ and $w_{1}^{*}=\underline{v}_{1}$ if $g$ cannot be contracted upon,

b) $g^{*}=g^{F B}$, and $w_{1}^{*}=\underline{v}_{1}-g^{F B}$, if $g$ is contractible.

The employer never pays for training in general skills because she cannot recover any returns from such training in the second period. If its training expenditures are noncontractible, this implies that no general human capital investments are made in equilibrium. Likewise, if $g$ is contractible and the firm can offer initial contracts $\left(w_{1}, g\right)$, any outlays in general training have to be borne entirely by the employee by receiving a first-period wage below his productivity. Expressed differently, if we let $\gamma$ be the worker's cost share and express the first-period wage as $w_{1}^{*}=\bar{w}_{1}-\gamma g$ where $\bar{w}_{1}$ is the wage component that is independent of $g$, then $\bar{w}_{1}=\underline{v}_{1}$ and $\gamma=1$ : the worker is paid

\footnotetext{
${ }^{9}$ See, e.g., Osborne and Rubinstein (1990). Malcomson (1997) provides an extensive discussion of how market opportunities can enter the negotiation outcome and when they take the form of outside options. This point is discussed in more detail in Section 3.
} 
his first-period marginal product and finances the full cost of his training out of his pay. ${ }^{10}$

\subsection{Investment in General and Specific Training}

We now return to the possibility of investment in the acquisition of firm-specific skills. To see how training in firm-specific skills alters equilibrium characteristics, reconsider the outcome of negotiations on second-period wage contracts. For $s>0$, there is now a positive rent $v_{2}(s, g, \theta)-w^{E}=v_{2}(s, g, \theta)-v^{G}(g, \theta)=v^{S}(s, \theta)>0$ to be divided between worker and firm. While this rent depends solely on the level of specific training $s$, the way in which it is shared depends also on $g$ as can be seen from (4). For $\alpha v_{2}<w^{E} \Leftrightarrow v^{S}<v^{G}(1-\alpha) / \alpha$, the worker's share of the surplus generated in the existing relationship falls short of what he can obtain on the external labor market: since his alternative market opportunity is binding, the negotiated second period wage is $w_{2}^{*}=w^{E}=v^{G}(g, \theta)$ and the rent from specific investments $v^{S}(\cdot)$ accrues entirely to the firm.

Conversely, the negotiated wage exceeds the outside market wage for $\alpha v_{2} \geq w^{E} \Leftrightarrow$ $v^{S} \geq v^{G}(1-\alpha) / \alpha$. In those states, the worker captures part of the rent generated through specific human capital accumulation through his share $\alpha$ of the overall surplus. His equilibrium wage then satisfies $w_{2}^{*}>w^{E}=v^{G}(g, \theta)$. As already noted by Becker, specific training investments imply that worker and firm are in a bilateral monopoly position after those investments have been made: if the worker quits and takes on another job, the firm's expenditures are wasted because no replacement worker would be equally proficient in the required task. Similarly, the specific skills are not marketable if the worker is laid off and he would therefore be unable to recoup any specific investments on this own part. As is well known, once worker and firm share the rent from specific investments, the 'Hold-up Problem' [Williamson (1985), Grout (1984)] arises and the firm will underinvest. The crucial point to recognize, however, is that the firm's holdup with respect to its specific investments is beneficial with respect to its incentives to invest into general skills: whenever the worker receives part of the surplus from the firm's expenditures on specific training, the firm at the same time captures part of the

\footnotetext{
${ }^{10}$ The proposition implicitly requires that the worker is not liquidity constrained, e.g., he can borrow against future wage income. Otherwise, although we still had $w_{1}^{*}=\underline{v}_{1}-g^{*}$, it may be the case that $g^{*}<g^{F B}$ if the worker might not be able to finance $g=g^{F B}$ out of his first-period pay (his productivity during the training period is sufficiently low).
} 
return on general training.

Formally, let $\Theta(s, g)=\left\{\theta \in[\underline{\theta}, \bar{\theta}]: v^{S}(s, \theta) \geq v^{G}(g, \theta)(1-\alpha) / \alpha\right\}$ denote the set of states in which rent sharing occurs for given investments $(s, g)$. Inserting the expression for $w_{2}^{*}$ from (4) into the firm's expected profit from the relationship, the latter can be written as

$$
\begin{aligned}
E[\pi(s, g, \theta)]=\underline{v}_{1}-w_{1}+ & \int_{\theta \in \Theta(\cdot)}(1-\alpha)\left[v_{2}(s, g, \theta)\right] d F(\theta) \\
& +\int_{\theta \notin \Theta(\cdot)}\left[v_{2}(s, g, \theta)-v^{G}(g, \theta)\right] d F(\theta)-g-s .
\end{aligned}
$$

Let us first focus on a situation where $g$ is not contractible so that the employer would not be willing to provide general training for $s \equiv 0$. If specific investments are allowed for, the firm chooses $(s, g)$ so as to maximize (5), subject to the non-negativity constraints $g \geq 0$ and $s \geq 0$. As is easily seen, the latter constraint is never binding and can be ignored. Substituting for $v_{2}(s, g, \theta)=v^{S}(s, \theta)+v^{G}(g, \theta)$, the first-order conditions that characterize equilibrium training outlays $\left(s^{*}, g^{*}\right)$ are

$$
\int_{\theta \in[\underline{\theta}, \bar{\theta}]} \frac{\partial v^{S}\left(s^{*}, \theta\right)}{\partial s} d F(\theta)-\alpha \int_{\theta \in \Theta(\cdot)} \frac{\partial v^{S}\left(s^{*}, \theta\right)}{\partial s} d F(\theta)=1,
$$

and

$$
(1-\alpha) \int_{\theta \in \Theta(\cdot)} \frac{\partial v^{G}\left(g^{*}, \theta\right)}{\partial g} d F(\theta) \leq 1, \quad=1 \text { for } g^{*}>0,
$$

where $\Theta(\cdot)$ is evaluated at $\left(s^{*}, g^{*}\right) \cdot{ }^{11}$ Hence,

Proposition 2. Suppose the firm can train the worker in specific and general skills and training expenditures are non-contractible. Then, its equilibrium training outlays $\left(s^{*}, g^{*}\right)$ are characterized by

a) $s^{*}<s^{F B}$ and $0<g^{*}<g^{F B}$ if $v^{S}\left(s^{F B}, \theta\right)>\underline{v}_{2} \frac{1-\alpha}{\alpha}$ for some realization of $\theta \in[\underline{\theta}, \bar{\theta}]$,

b) $s^{*}=s^{F B}$ and $g^{*}=0$ otherwise.

Thus, the firm invests in general training if and only if hold-up with respect to specific training occurs with positive probability.

\footnotetext{
${ }^{11}$ It is straightforward to verify that $E[\pi(s, g)]$ is concave in $(s, g)$. Equilibrium training outlays $\left(s^{*}, g^{*}\right)$ are therefore unique and fully determined by (6) and (7). Also note that small changes in training outlays that affect the set of states in which surplus-sharing occurs do not enter the first-order conditions by definition of $\Theta(\cdot)$ and continuity of $F(\theta)$.
} 
Under our assumptions on $v_{2}(\cdot)$, the claim follows directly by comparing (6) with (2) and by inspection of (7). A formal proof is therefore omitted. The intuition for this finding has already been laid out in the preceding discussion. If hold-up occurs in some states of the word, the employee captures a fraction $\alpha$ of the surplus from the firm's expenditures in his acquisition of specific (as well as general) skills. At the same time, however, the firm is also able to recover part of its expenditures on general training on the margin. This is true even though rent sharing implies that the firm's overall profit from both types of training decreases relative to a situation where the employee's alternative market opportunity is binding. Expressed differently, the firm captures part of the return from its general training outlays although the worker always receives at least his marginal product from general training. ${ }^{12}$ Hold-up with respect to specific investments $\left(s^{*}<s^{F B}\right)$ can only be avoided if, given efficient specific and no general training, the external wage of a worker with no marketable skills, $w^{E}=\underline{v}_{2}$, is sufficiently high so as to make his outside market opportunity binding in every state of the world, i.e., $\Theta\left(s^{F B}, 0\right)=\emptyset$, or equivalently, $v^{S}\left(s^{F B}, \theta\right) \leq \underline{v}_{2} \frac{1-\alpha}{\alpha}$ for all realizations of $\theta$. Otherwise, however, hold-up will occur and it is optimal for the employer to provide a positive amount of general training. Finally, note that since $s^{*}>0$, the firm expects to realize a positive second-period profit. On a competitive labor market, those future profits will be competed away by means of first-period wage payments. Formally, we have $E\left[\pi\left(s^{*}, g^{*}, \theta\right)\right]=0 \Rightarrow w_{1}^{*}>\underline{v}_{1}$, i.e., the firm's rents from human capital accumulation are appropriated by the worker through a rise in his first period wage.

At first glance, the statement in Proposition 2 may lead one to conclude that a firm's investment in general human capital negatively distorts the accumulation of specific human capital relative to a situation where general training is absent, $g \equiv 0$. The following result asserts that this conclusion is misleading:

Proposition 3. The firm's expected-profit function (5) is supermodular in $s$ and $g$. Therefore, general and specific training are complementary from the firm's point of view and its optimal investments into specific human capital $s^{*}(g)$ are nondecreasing in the level of general human capital $g$ (and vice versa).

Proof. See the Appendix.

\footnotetext{
${ }^{12}$ It is important to observe that this property of our model differs from the existing literature where wages are 'compressed' and workers receive less than the marginal productivity associated with their general skills. See Section 3 for a discussion.
} 


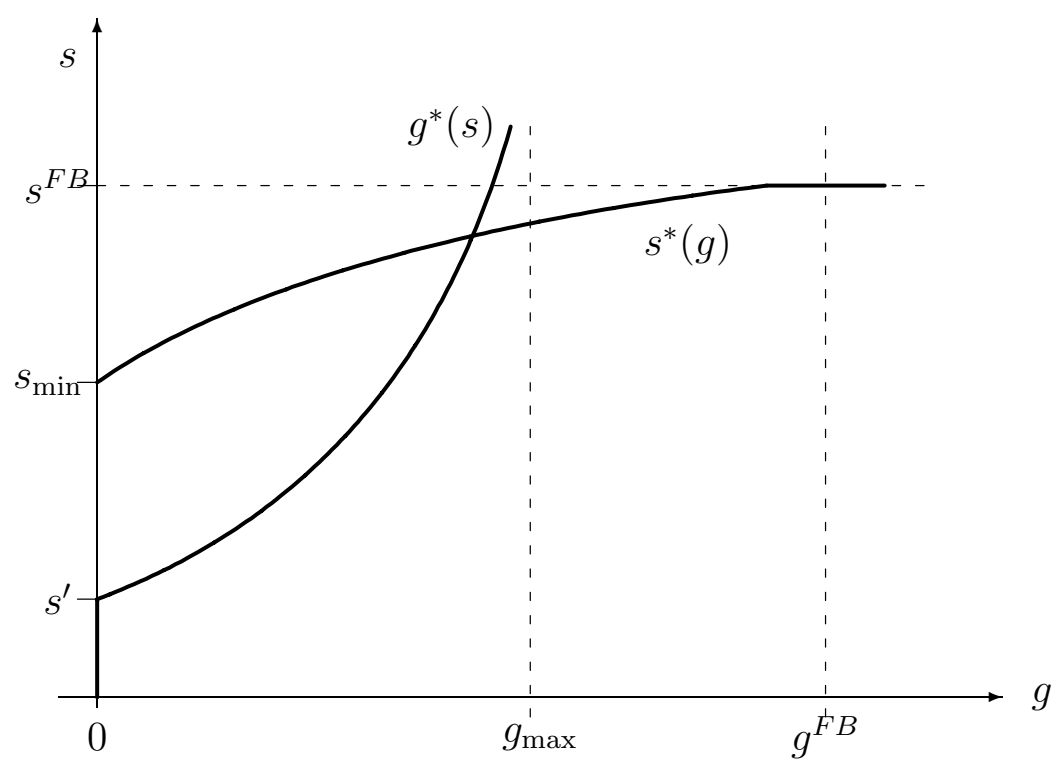

Figure 2: Training Outlays

Intuitively, employees with a high level of general training receive higher external wage offers than those with fewer or no general skills. The outside market opportunity of workers with more general training will therefore bind more frequently, ceteris paribus. Although the firm has to match the external wage in those states, it at the same time reaps the full marginal return from its specific training outlays (rent sharing does not occur) and its incentives to provide specific training rise. In other words, general training alleviates the hold-up problem that arises from the parties' lock-in in a bilateral monopoly situation.

Figure 2 illustrates the above arguments. It depicts the firm's optimally chosen expenditures in specific training $s^{*}$ (respectively, general training $g^{*}$ ) as a function of a given level of $g$ (respectively, $s$ ). If the worker had no general training, the firm would provide specific training of $s^{*}(0)=s_{\min }$ which solves (6), evaluated at $\Theta\left(s_{\min }, 0\right)$. The specific training outlays $s^{*}(g)$ increase thereafter until $g$ is sufficiently high that surplus sharing no longer occurs so that the firm invests efficiently, independent of $g$. Conversely, no general training would be provided if $s=0$ and this continues to be optimal up to some $s=s^{\prime}$ at which point surplus sharing occurs with positive probability, i.e., $\Theta(s, 0)$ is non-empty for $s \geq s^{\prime}$. ¿From then on, the provision of general training $g^{*}(s)$ increases because the likelihood of a surplus sharing outcome increases in $s$, ceteris paribus. If 
this probability is equal to one, $g^{*}$ is maximal and given by $g_{\max }<g^{F B}$ which solves (7) for $\Theta=[\underline{\theta}, \bar{\theta}]$. The equilibrium outlays $\left(s^{*}, g^{*}\right)$ characterized in Proposition 2 can be found at the intersection of both curves. As long as $s_{\min }<s^{F B} \Leftrightarrow \Theta\left(s^{F B}, 0\right) \neq \emptyset$, the intersection point is characterized by $g^{*}>0$. Otherwise, we have $s_{\min }=s^{F B}$ which implies $s^{\prime}>s^{F B}$ by definition of $s^{\prime}$ so that the curves intersect on the axis where $g^{*}=0$. Also note that the effect of a drop in the worker's bargaining power does not necessarily encourage firm-sponsored general training: a reduction in $\alpha$ reduces the probability that surplus sharing occurs, thus shifting $s^{*}(g)$ upwards. Since $g^{*}(s)$ also shifts upwards by the same token, however, the composite effect is ambiguous.

Let us now turn to the case where $g$ is contractible so that the firm can offer an initial contract $\left(w_{1}, g\right)$. For a precontracted level of general training $g$, the firm's expenditures on specific training $s^{*}(g)$ are determined by (6) and its associated expected profit is (5) evaluated at $\left(s^{*}(g), g\right)$. Consider a first-period contract that involves $g=g^{F B}$. From our previous analysis, we already know that the share of general training outlays borne by the worker is strictly less than one if $\Theta\left(s^{*}\left(g^{F B}\right), g^{F B}\right)$ is non-empty. This condition is equivalent to $s^{*}\left(g^{F B}\right)<s^{F B}$ or

$$
v^{S}\left(s^{F B}, \theta\right)>v^{G}\left(g^{F B}, \theta\right) \frac{1-\alpha}{\alpha} \text { for some } \theta \in[\underline{\theta}, \bar{\theta}] .
$$

The argument here is essentially the same as in Proposition 2. If hold-up with respect to specific training prevails, the firm captures part of the surplus from general training and is therefore willing to bear a positive share of those expenses. In this case, though, the equilibrium contract does not prescribe a first-best amount of general training:

Proposition 4. Suppose the firm can train the worker in general and specific skills and the amount of general training can be contracted upon. If (8) holds, equilibrium training outlays satisfy $s^{*}<s^{F B}$ and $g^{*}>g^{F B}$. In this case, the worker does not bear the full cost of his general training. Otherwise, $\left(s^{*}, g^{*}\right)=\left(s^{F B}, g^{F B}\right)$ and the worker's share of general training expenditures is equal to one.

Proof. See the Appendix.

The result states that worker and firm do not necessarily agree on the first-best level of $g$ even though such a contract is feasible. ${ }^{13}$ Rather, they may well decide on a in-

\footnotetext{
${ }^{13}$ Again, a contract prescribing $g^{*} \geq g^{F B}$ may not be feasible if the employee is wealth constrained. Note, however, that the presence of specific training facilitates an agreement on $g$ because the firm's second-period rent generated by the worker's specific skills raises first period wages, thereby relaxing his liquidity constraint.
} 
efficiently high provision of general training. Although perhaps surprising, this finding is easily explained: suppose at a precontracted level of general training $g^{F B}$, the firm's (unilaterally chosen) expenditures on training in specific skills fall short of $s^{F B}$. Obviously, a small increase in $g$ above $g^{F B}$ has only a second order effect on the returns to general training. Since general and specific training are complementary from the firm's point of view by Proposition 3, however, it improves the firm's incentives to engage in specific training. But raising $g$ has a positive first-order effect on the joint surplus from specific human capital accumulation. Thus, the worker optimally receives 'too much' general training in order to reduce a prevailing hold-up problem with respect to the firm's specific human capital investments. ${ }^{14}$

Before concluding this section, let us briefly indicate how the above results change if it is instead the worker who decides how much to invest in his general skills, while the firm decides on how much specific training training he is to receive. First, it is immediate that the outcome remains unaffected in a situation where $g$ is contractible. Since the contractually agreed upon level of $g$ is always chosen so as to maximize joint surplus, (residual) decision rights do not matter and Proposition 4 continues to hold. Next, recall that in the absence of specific training $(s \equiv 0)$, the worker receives the full marginal product from his general skills and would therefore invest efficiently even if $g$ cannot be contracted upon. Clearly, this argument carries over to the case where the firm invests in $s$ but the employee's outside option is binding, i.e., surplus sharing never occurs. Otherwise, however, surplus sharing implies that he does not capture the full return from his investments at the margin and, as a result, underinvests. The outcome if $g$ is non-contractible and chosen by the worker thus inversely mirrors the result in Proposition 3. The equilibrium level of general training is efficient if holdup with respect to specific training does not occur with positive probability [the set $\Theta\left(s^{F B}, g^{F B}\right)$ is empty] and inefficiently low (but positive) otherwise.

\subsection{Extensions}

This section briefly considers two natural extensions of the basic model: the possibility of (equilibrium) labor turnover and the implications of long-term contracts.

\footnotetext{
${ }^{14}$ Contrary to what has sometimes been suggested, complaints about German apprentices spending 'excessive' time in vocational schools may therefore be unjustified.
} 


\section{Layoffs and Quits}

In our previous discussion, there was no reason for a firm to lay off workers or for employees to quit their jobs: the joint surplus in an ongoing relationship always exceeded the corresponding surplus after separation due to the firm-specific skills of the employee. ${ }^{15}$ Firm and worker therefore could always find a second-period wage scheme that made a continuation profitable for both parties. The possibility of equilibrium labor turnover can be incorporated into our basic model in a simple way. Suppose that in addition to the employee-specific (or industry-wide) shock $\theta$, there is another purely match-specific shock $\lambda \geq 0$ that is observed by both parties and positively affects the parties' payoff if they terminate the relationship and take up their outside market opportunities in period 2. For example, the worker may learn that he dislikes his colleagues or that his spouse has found employment in another state. Alternatively, the firm may discover that the worker is unable to adapt to its corporate culture. Irrespective of which party experiences the shock $\lambda$, separation in $t=2$ is then efficient if and only $v_{2}(s, g, \theta)<w^{E}+\lambda$ or, equivalently, $v^{S}(s, \theta)<\lambda$ after using (1) and $w^{E}=v^{G}(g, \theta)$. In such a situation, firm and worker can do no better than taking up their respective outside opportunities, i.e., the worker optimally quits or is laid off, respectively. In states where $v^{S}(s, \theta) \geq \lambda$ so that continuation is efficient, the outcome of wage negotiations as described in Assumption 3 remains valid with $\pi^{E}$ or $u^{E}$ adjusted for $\lambda$. Clearly, the external market opportunities will bind more often, thereby reducing the likelihood of a rent-sharing outcome. By our previous arguments, the amount of general training that the firm is willing to provide on its own account in equilibrium will thus be lower, ceteris paribus. ${ }^{16}$ As long as the firm's specific investments are sufficiently high so that rent-sharing (hold-up) occurs with positive probability, however, we still have $g^{*}>0$. Finally, note that the effect of $\lambda$ on the firm's equilibrium outlays in specific training is ambiguous. On the one hand, the return from specific training falls if the relationship is terminated with positive probability since specific skills are valued only within an existing match. On the other hand, the firm has to share the rent from its specific investments less frequently because the likelihood that surplus-sharing occurs is reduced.

\footnotetext{
${ }^{15}$ Recall from Assumption 1 that $v_{2}(s, g, \theta)$ is increasing in $s$ and $v(0, g, \theta)=v^{G}(g, \theta), \forall g, \theta$.

${ }^{16} \mathrm{As}$ is easily seen, the first-best general training outlays $g^{F B}$ are unaffected by the possibility of efficient separation because general skills increase the value of a worker irrespective of whether he stays with his current employer or not.
} 


\section{Long-term Contracts}

Since employment contracts frequently expand beyond a short time horizon, it is important to study long-term arrangements and their effects on the formation of human capital. ${ }^{17}$ For concreteness, let us consider long-term contracts offered in stage 0 that take the form $\left(w_{1}, w_{2}\right)$, specifying a fixed wage $w_{t}$ if the worker is employed in period $t$. Also, let us for the moment suppose that the initial contract cannot be renegotiated, and let us confine attention to the case where separation is never efficient, i.e., employment should always continue beyond the training period. Consider a second period wage

$$
0 \leq w_{2} \leq \inf _{\theta} v_{2}\left(s^{F B}, g^{F B}, \theta\right)
$$

so that continued employment in $t=2$ would be preferred by both, given the firm invested efficiently. If the parties ex ante sign a second-period wage from that interval and the worker can be prevented from taking his outside market opportunity, the firm becomes residual claimant for the return from both types of training and, as a consequence, chooses efficient training. However, in presence of outside opportunities a contract $\left(w_{1}, w_{2}\right)$ satisfying $(\mathrm{C} 1)$ is not sufficient to ensure first-best investments: as long as employment is on an at-will basis, the worker could still take up his external market opportunity in $t=2$ and would optimally do so whenever $w^{E}>w_{2}$. Since the return from both general and specific training is lost for the firm if the worker quits, it would underinvest (see below).

There is a simple remedy to this problem. Suppose that the contract can (in addition to $w_{t}$ ) stipulate a breach penalty $P$ paid by the worker to the firm that becomes due once the employee quits and switches to an outside employer at the beginning of the posttraining period. A sufficiently high penalty could - if enforceable - then serve to protect the firm's training outlays. In particular, for a breach penalty $P \geq \sup _{\theta} v^{G}\left(g^{F B}, \theta\right)-$ $w_{2}$, the worker never takes up outside employment because the fine he would have to pay in this case exceeds the highest possible external market wage (provided his general training does not exceed $\left.g^{F B}\right) .{ }^{18}$ As long as the fixed wage $w_{2}$ satisfies $(\mathrm{C} 1)$, the firm obtains the full return from its investments on the margin. Moreover, the first-period wage $w_{1}$ can be adjusted to ensure non-negative profits. The firm would thus invest efficiently both in general and specific skills. In view of their simplicity

\footnotetext{
${ }^{17}$ See Malcomson (1997) for a comprehensive survey.

${ }^{18}$ This reasoning requires the legal system to allow for such penalties in employment contracts. Also, the worker must be able to pay the penalty if necessary.
} 
and apparent advantages, one might thus ask why such breach penalties are rarely observed in employment relationships where training is likely to play an important role. One obvious reason is that courts are reluctant to enforce breach penalties that de facto represent an exclusive dealing clause, thereby eroding the at-will nature of employment contracts. This will be particularly so if the breach remedy $P$ necessary to ensure efficient investments is much larger than the actual damage the firm incurs from breach [Malcomson (1997)]. Another more fundamental explanation may be that for the penalty to be effective, it must be contingent on the identity of the breaching party. If $P$ had to be paid irrespective of who was responsible for separation, the firm would become eligible for the payment if it took a unilateral action, i.e., dismissed the employee. As a result, the worker would be (inefficiently) laid off in some states and the firm would underinvest. But it may be quite impossible for an outsider to determine who was responsible for the termination of the relationship, e.g., quits and layoffs may be indistinguishable.

If (contingent) breach penalties are not enforceable, it is less straightforward to achieve efficient investments. To see this, note that for the firm never to lay the worker off, the initially agreed upon second period wage must satisfy $w_{2} \leq \inf _{\theta} v_{2}\left(s^{F B}, g^{F B}, \theta\right)$. Similarly, for the worker never to quit, we must have $w_{2} \geq \sup _{\theta} v^{G}\left(g^{F B}, \theta\right)$. Taken together, these two inequalities can only hold if

$$
\inf _{\theta} v_{2}\left(s^{F B}, g^{F B}, \theta\right) \geq \sup _{\theta} v^{G}\left(g^{F B}, \theta\right),
$$

i.e., the smallest conceivable surplus inside the relationship must exceed the highest conceivable wage on the external labor market, given efficient investments. ${ }^{19}$ As long as there is some uncertainty in second-period productivity of a skilled worker, (C2) is quite restrictive: the difficulty lies in the fact that (efficient) voluntary continuation of the relationship has to be ensured, i.e., it must be possible to find the fixed secondperiod wage such that a quit or a layoff is never unilaterally optimal for either party. ${ }^{20}$

\footnotetext{
${ }^{19}$ Condition (C2) must also hold if the initial contract comprises a (redundancy) payment $p$ which becomes effective in case of separation (and is independent of who is responsible for separation to occur). To see this, observe that the relevant inequalities are then $p \leq \inf _{\theta} v^{2}\left(s^{F B}, g^{F B}, \theta\right)-w_{2}$ and $w_{2} \geq \sup v^{G}\left(g^{F B}, \theta\right)-p$, again implying (C2).

${ }^{20}$ Of course, the parties may renegotiate the initial contract instead of terminating their their relationship if separation is not efficient. A discussion of this issue can be found in Kessler and Lülfesmann (2000), which draws on the work of MacLeod and Malcomson (1993a, 1995). If $g$ is not contractible, renegotiations further impede the possibility of inducing efficient training, at least under the simple contractual arrangements we consider. If $g$ is contractible, however, long-term schemes with (noncontingent) termination payment generically implement efficient specific investments [those can be determined along the lines of MacLeod and Malcomson (1993a), see Proposition 7 in their paper].
} 
Finally, observe that efficient firm-sponsored general training is even more difficult to achieve if it may be optimal for the parties to separate. Intuitively, if the worker (efficiently) quits, the training firm does not recover any surplus from its general investments. Since it does not take into account the positive externality general investments have on the worker's outside productivity, underinvestment prevails. This argument holds even if contingent breach penalties are feasible: if the fee is small so that the worker quits in spite of the penalty, the employer obtains no return from her general investments. Conversely, if the fee is large so efficient separation requires renegotiation, the employer appropriates only a fraction of the marginal returns from training investments as long as the worker has some bargaining power. Again, the firm does not fully internalize the externality generated by its training outlays. ${ }^{21}$

\section{Discussion}

In his seminal work, Becker (1964) drew the important distinction between general and specific investments in human capital. If the skills a worker acquires through on-thejob training are purely general, he argued, the wage on the external labor market will reflect the full marginal product from this training. Thus, workers capture the entire return from their general human capital in a competitive labor market. Conversely, training in perfectly specific skills has no effect on the worker's productivity in other firms and the wage that an employee could get elsewhere would thus be independent of the amount of training he received. As a consequence, the return to specific human capital is shared between employees and firms. Becker concluded that employees must bear all the costs of their general training whereas the costs of specific training are shared between workers and firms. ${ }^{22}$ As noted earlier, however, the first prediction is at odds with empirical work on firm-sponsored formal training programs whose content is general in nature. The present framework reconciles Becker's theory with empirical evidence in a framework that preserves its two main characteristics: a) the worker always receives the full return from general training and b) obtains a share of the return (rent) generated by specific training. The sole difference lies in the fact that we do not consider each type of human capital investment separately but rather allow

\footnotetext{
${ }^{21}$ In a model with labor market frictions, Acemoglu (1997) shows that this result even applies when general investments are contractible.

${ }^{22}$ For a formal analysis on how the costs of specific investments are shared, see Hashimoto (1981).
} 
for both general and specific training to be provided at the same time. ${ }^{23}$ Once this possibility is taken into account, the sharp conclusion that firms should never pay for investments in general training no longer applies. Moreover, this result does not rely on general and specific skills being complements in production (or training expenditures) as the previous analysis has shown.

A body of recent research has suggested several reasons of why and under which circumstances firms may be willing to contribute to the costs of general training. One prominent explanation is based on informational asymmetries between the training firm and potential future employers. ${ }^{24}$ If the outside market is not as well informed as the current employer about a worker's level of training or his other relevant characteristics, the worker's general skills are no longer perfectly marketable and in essence become specific skills. An analogous line of reasoning applies if there are labor market frictions created by search or hiring costs [Acemoglu (1997)]. In both cases, workers receive less than their marginal product from (general) training on average which improves firms' investment incentives. Acemoglu and Pischke (1999) note further labor market imperfections where wages are below marginal product and rise less steeply than productivity so that the wedge between marginal product and (outside) wage is higher, the more trained a worker is. ${ }^{25} \mathrm{~A}$ similar mechanism is at work in our framework: although external wages are equal to worker's marginal product from general training, the wage he obtains if he stays with the training firm rises by less than his overall productivity. Furthermore, the resulting gap is an increasing function of his level of specific training.

Although this property of our model is generated by the outcome of wage bargaining as formalized in Assumption 3, it does not critically depend on the utilization of the outside option principle. Implicit in this particular bargaining solution is the assumption that the default payoff each party receives in the course of bargaining is zero or, more importantly, independent of investments. In other words, the default payoffs in case of a disagreement during negotiations are unaffected by what the parties' can obtain on the external market. To consider the opposite polar case, suppose the worker's default

\footnotetext{
${ }^{23}$ Note that our model is formally equivalent to the Becker's framework and yields identical predictions for $s \equiv 0$ and $g \equiv 0$, respectively.

${ }^{24}$ See Katz and Zidermann (1990), Chiang and Chiang (1990), Chang and Wang (1996), and Acemoglu and Pischke (1998). For an analysis of what long-term (apprenticeship) contracts can achieve in this context, see Malcomson et al. (1999).

${ }^{25}$ Apart from informational asymmetries, the authors study three situations where such a 'compressed' wage structure is likely to arise: union wage setting, minimum wages, and worker moral hazard.
} 
payoff is identical to what he could obtain if he were to quit permanently, i.e., equal to $w^{E}$. Then, the gain from reaching an agreement would no longer be $v_{2}(s, g, \theta)$ but rather $v_{2}(s, g, \theta)-w^{E}=v^{S}(s, \theta)$ and would thus be unaffected by general training outlays $g$. If the parties share this gain according to their relative bargaining powers, equilibrium payoffs would be $u_{2}^{*}=w^{E}+\alpha v^{S}(\cdot)$ and $\pi_{2}^{*}=(1-\alpha) v^{S}(\cdot)$. As the latter is independent of $g$, the firm would have no incentive to invest in general skills. ${ }^{26}$ To assess this, notice that for the employee's threat point to be $w^{E}$, he must be able to take on a temporary job for one bargaining round that pays the same wage $w^{E}$ as a permanent job on the external labor market. Indeed, one can formalize the notions of alternative market opportunities acting a threat points (in the sense of Nash-bargaining) and as outside options as two limit cases of a non-cooperative alternating offers game. In the former case, the minimum time period for which the worker has to stick to an outside employer is one bargaining round whereas it approaches infinitely many rounds in the latter [see Chiu and Yang (1999)]. ${ }^{27}$ As we have seen above, our results are not valid when the employee can switch to an outside employer and return after only one round of bargaining. For all intermediate cases, however, the worker's disagreement payoff does not rise one-to-one with his external market opportunity and our analysis continues to apply. More generally, what matters qualitatively is that negotiations do not follow exactly the Nash-solution, where the worker's threat point (and his final payoff from bargaining in our formulation) rises one-to-one with his outside option. This condition is testable and appears to be satisfied in practice [see, e.g., Binmore, Shaked and Sutton (1989), Knez and Camerer (1995) and Kahn and Murnighan (1993) for experimental evidence and Scaramozzino (1991) for econometrical evidence in a study of the UK manufacturing industry].

On the empirical side, our approach has a number of implications that are similar to those of the existing literature. For example, since equilibrium turnover is lower the

\footnotetext{
${ }^{26}$ Formally, the additively separable structure of marginal products would be fully reflected in the worker's post-training wage. There would be no interaction between the two types of skills and Becker's original argument would fully carry over to a situation where both general and specific training is provided.

${ }^{27}$ In this case, the external market opportunity, if taken terminates the relationship and must be represented as an outside option. Alternatively, the distinction can be made based on search or relocation costs that are associated with finding an equally good job outside the current relationship. The worker will optimally bear those only if the new job is expected to last for some time. In particular, as the time spent in negotiations (the time interval between offers) becomes very small, such turnover costs - even if they are arbitrarily low - are worth incurring only if the outside job is permanent. See Malcomson (1997) for the same argument and a further discussion along those lines.
} 
higher the level of firm-specific skills, one would expect lower turnover rates in industries where specific investments are very viable. The complementarity result in Proposition 3 then implies a negative correlation between both types of training and equilibrium turnover although low turnover rates per se do not improve a firm's incentives to provide general training as has sometimes been suggested [Blinder and Krueger (1996)]. By the same token, since the equilibrium level of general training in our model depends (among other things) on its contractibility, the model predicts that both general and specific training are higher in countries where institutionalized training programs make the amount of general training more easily enforceable. If one reasonably presumes that this is the case for, e.g., Germany relative to the United States, our results suggest that there should also be more specific training and, hence, lower turnover rates in Germany than in the United States. Finally, surplus sharing implies that the post-training wage increases by less than a worker's productivity.

All those predictions are supported by the data ${ }^{28}$ and although they stand in contrast to the classical theory (where turnover should be independent of the level of general training and wages should grow at the same rate as productivity), they are also implied by, e.g., models that rely on informational asymmetries to explain firm-sponsored general training. ${ }^{29}$ Let us therefore next discuss some empirical findings that are difficult to reconcile with the existing literature but may be accounted for by the interaction of general and specific training.

First, supporting evidence for the present model may lie in the significant differences

\footnotetext{
${ }^{28}$ The positive correlation between general training and retention rates is reported, e.g., in Blinder and Krueger (1986). Topel and Ward (1992) and Soskice (1994) find that the average number of jobs held by US employees during the first ten years of their career is about five, but only one or two in Germany. Blanchflower, Oswald and Sanfrey (1996) find that an increase in profit per worker raises wages only at a rate of at most 0.3 and Loewenstein and Spletzer (1998) estimate that a worker's return on employer-sponsored specific and general training is very similar, suggesting that surplussharing between firm and employer is prevalent.

${ }^{29}$ Asymmetric information is certainly a relevant phenomenon, although perhaps less so in countries with formal training programs like Germany where apprentices receive upon completion a nationwide accepted certificate which acknowledges their skill and overall training success. The certificate should reduce uncertainty in particular with respect to the amount of training received. In contrast, the unknown characteristic in Acemoglu and Pischke (1998) is the ability of the apprentice of which standardized exams may provide only a very noisy signal. Also, their empirical test supports the presence of adverse selection, because the salaries of employees that leave because they are drafted to the military (quits caused by exogenous reasons) are significantly higher that the salaries of those that either leave voluntarily or have been laid off. Our model cannot adequately account for these differences, which emphasizes the importance of adverse selection phenomena as a complementary explanation for the prevalence of general training.
} 
in training expenses across sectors of the German economy. Franz and Soskice (1995) estimate the average yearly net training cost per apprentice at about DM 15000 in the industrial sector which largely consists of medium and large scale enterprises, and at only about DM 7000 per worker in the crafts and artisan sector ("Handwerk"). Similar results are found in von Bardeleben, Beicht and Feher (1995) who estimate that large firms with more than 500 employees have positive net training costs of about DM 7500 per employee, while the costs for the smallest firms with less than 10 employees [usually from the Handwerk sector] are close to zero or may even be negative.

These patterns are somewhat surprising because the formal structure of apprenticeship programs in the two sectors is more or less the same, and it is not immediate why informational asymmetries or search costs should systematically differ between industrial and crafts sector. However, it seems quite plausible that firm-specific training is of considerable importance in large enterprises which are characterized by complex internal structures. In fact, Franz and Soskice (1995, p.220) note that "[...] in Germany, the requirements of a skilled worker [in the industrial sector] have radically changed. By contrast to the traditional craftsman or to a tradesman in a Fordist company who had a set of standardized skills which they could use in many different environments, the modern skilled employee plays a complex interactive role in the production, maintenance, organization of new processes, and so on." In light or our findings, the differences in employer-sponsored training between the industrial and the crafts sector of the German economy may thus be traced back to the differences in the viability of specific training. This view is confirmed by the observation that retention rates after the completion of the apprenticeship program vary significantly with firm size: Soskice (1994) reports that the retention rates in small German firms with 5-9 employees are about 0.56, while they increase in firm size and reach a rate of 0.87 for companies with more than 1000 employees. This sample also exhibits a relation between the employer's willingness to invest in general training and firm size: while about 41 percent of firms of less than 50 employees (and even 65 percent of firms with 5-9 workers) do not participate in formal training programs which are general to a large degree, the fraction of non-training firms continuously shrinks and becomes negligible for firms with more than 500 employees. This finding is in line with our theoretical results, where a high relevance of specific training leads not only to low turnover rates, but goes hand in hand with a more pronounced provision of firm-sponsored general training.

Second, recall from Section 2.3. that the model predicts the usage of breach penalties 
as an instrument for firms to protect their training outlays. Although breach penalties drive a wedge between a worker's marginal product and his outside market opportunities, the difference is independent of the amount of training received. In existing models, therefore, penalty payments should have no effect on a firm's incentive to train, irrespective of whether or not further market imperfections are present. ${ }^{30}$ As discussed above, such clauses are frequently subject to legal restrictions. Nevertheless, they exist in reality. One example is the German revenue service which trains students in a three-year trainee program who later serve as tax officials. If graduates quit the service within five years after completion of the program, they are subject to a breach penalty of about DM 25000. Similar clauses are used by German mining companies that provide advanced training programs in engineering. Also observe that the use of vested stock as part of an employee's compensation package may serve as a substitute for explicit breach penalties if those are difficult to enforce. ${ }^{31}$

Finally, our analysis can account for the fact that employers frequently sponsor general training of their employees only simultaneously with or after a period of in-house training. ${ }^{32}$ If in-house training is partly relationship-specific, it may take some time until a worker's specific skills generate sufficient additional surplus until his outside wage falls short of the negotiated equilibrium wage inside the current relationship which is a prerequisite for general training to be viable. Expressed differently, if general investments would be provided prior to the specific training, outside employers could poach the worker upon completion of the general training period, and then train him in firm-specific skills themselves. In such a situation, the firm recovers no return from general investments in the first period, and would rationally postpone its participation in

\footnotetext{
${ }^{30}$ The effectiveness of breach penalties hinges on the presumption that bargaining follows the outside option principle. It is important to note that they cannot serve this purpose if external market opportunities act as threat points rather than outside options.

${ }^{31}$ We thank George Baker for pointing this out to us.

${ }^{32} \mathrm{Yu}(1999)$ conducts a survey of evening MBA students at the HAAS business school at UC Berkeley. About 80 percent of the students had partial to full tuition (which amounts to $\$ 19.000-\$ 24.000$ annually) paid for by the companies for which they work. He finds that the number of years an employee had worked for the company (as a proxy for the amount of firm-specific training the worker has acquired) has a significant positive impact on the percentage of firm-sponsored education. Likewise, large consulting firms such as McKinsey and Co. generally offer employees with two of more years of job tenure the possibility to take a paid leave in order to participate in MBA programs or complete their doctoral degrees. Importantly, the corresponding contract is signed at the beginning of the employment relationship, i.e., at a time where the company presumably has no more information on the employee's ability than other firms. Of course, such offers may also serve as screening devices in recruitment. This alternative explanation, however, cannot account for the the contractually specified time sequence.
} 
general training until a sufficient level of specific human capital has been accumulated.

\section{Concluding Remarks}

This paper has studied a situation where the firm can invest in general as well as firm-specific human capital of its employees. Our main result was that these types of investments interact even if no technological link exists. Specifically, specific training not only renders the provision of general training viable for an employer, but the reverse also holds: the higher the level of a worker's general human capital, the larger are the firm's incentives to train him in specific skills. The finding therefore indicates that specific and general training are 'incentive' complements from the employer's point of view. As a consequence, employers may be willing to sponsor general training even in competitive labor markets where outside wages fully reflect a worker's marginal product from his general human capital.

We have argued that there is not only evidence that firms sponsor general human capital accumulation of their workers, but also evidence that suggests the complementarity in the provision of general and specific training. Whether this complementarity can mainly be attributed to technological reasons or to the interaction we posit in the present paper is an empirical question which future research needs to address. We should emphasize, though, that our model does not preclude the possibility of a technological link between both types of training, be it on the output or on the cost side of production. The positive incentive effect that we have isolated in our analysis should be present irrespective of whether general and specific training are technological complements or substitutes. 


\section{Appendix}

\section{Proof of Proposition 3}

By definition, $E[\pi(s, g)]$ is supermodular in $(s, g)$ if and only if $\partial E\left[\pi\left(s, g^{\prime}\right)\right] / \partial s \geq$ $\partial E[\pi(s, g)] / \partial s$ for all $s$ and $g^{\prime}>g$. Using (6), this condition is equivalent to

$$
g^{\prime}>g \Rightarrow \int_{\theta \in \Theta^{\prime}} \frac{\partial v^{S}\left(s^{*}, \theta\right)}{\partial s} d F(\theta) \leq \int_{\theta \in \Theta} \frac{\partial v^{S}\left(s^{*}, \theta\right)}{\partial s} d F(\theta), \quad \forall s,
$$

where $\Theta^{\prime} \equiv \Theta\left(s, g^{\prime}\right)$ and $\Theta \equiv \Theta(s, g)$. Since $g^{\prime}>g \Rightarrow v^{G}\left(g^{\prime}, \theta\right)>v^{G}(g, \theta)$ for all values of $\theta$, we have $\theta \in \Theta^{\prime} \Rightarrow \theta \in \Theta \Leftrightarrow \Theta^{\prime} \subseteq \Theta$, which together with $\partial v^{S}\left(s^{*}, \theta\right) / \partial s>0$ implies (9). Also observe that the inequality in (9) is strict whenever either $\Theta \neq \emptyset$ or $\Theta^{\prime} \neq[\underline{\theta}, \bar{\theta}]$.

Proof of Proposition 4

The equilibrium contract $\left(w_{1}^{*}, g^{*}\right)$ when $g$ is contractible maximizes expected surplus $S(g, s) \equiv$ $E_{\theta}\left[v_{2}(s, g, \theta)\right]+\underline{v}_{1}-s-g$ subject to $s=s^{*}(g)$ and $E[\pi(s, g)] \geq 0$.

Suppose first by way of contradiction that (8) is satisfied but $g^{*} \leq g^{F B}$. Now consider a contract $g^{\prime}=g^{*}+d g$ with $d g>0$. Using (6), the change in expected surplus for $d g$ small is

$$
d S=\left[\int_{\theta} \frac{\partial v^{G}\left(g^{*}, \theta\right)}{\partial g} d F(\theta)-1\right] d g+\left[\alpha \int_{\theta \in \Theta} \frac{\partial v^{S}\left(s^{*}, \theta\right)}{\partial s} d F(\theta)\right] \frac{\partial s^{*}(g)}{\partial g} d g .
$$

Note that by (3), the first term in brackets is non-negative for any $g^{*} \leq g^{F B}$. Likewise, under condition (8), $\Theta\left(s^{F B}, g^{*}\right)$ is non-empty for any $g^{*} \leq g^{F B}$. (6) then implies $s^{*}\left(g^{*}\right)<s^{F B}$ so that the second term is strictly positive. Furthermore, $\partial s^{*} / \partial g>0$ for $\Theta\left(s^{*}(g), g\right) \neq \emptyset \Leftrightarrow s^{*}<s^{F B}$ from the proof of Proposition 3. Thus, $d S>0$, contradicting our presumption that $g^{*} \leq g^{F B}$ is part of an equilibrium contract (an analogous argument can be applied to show that we must have $s^{*}<s^{F B}$ in equilibrium).

If we decompose $w_{1}=\bar{w}_{1}-\gamma g$ again, we find using (1) and (5),

$$
\begin{aligned}
\bar{w}_{1} & =\underline{v}_{1}+\int_{\theta \in[\underline{\theta}, \bar{\theta}]} v^{S}\left(s^{*}(g), \theta\right) d F(\theta)-\alpha \int_{\theta \in \Theta} v^{S}\left(s^{*}(g), \theta\right) d F(\theta)-s^{*}(g)>\underline{v}_{1} \\
\text { and } \quad \gamma & =1-(1-\alpha) \int_{\theta \in \Theta}\left[v^{G}(g, \theta)-c\right] d F(\theta) / g .
\end{aligned}
$$

The corresponding value of $\gamma$ can be obtained by evaluating (10) at $g^{*}$. Since $\Theta\left(s^{*}, g^{*}\right)$ is non-empty, we have $\gamma<1$.

Finally, suppose (8) is not satisfied, i.e., $\Theta\left(s^{F B}, g^{F B}\right)=\emptyset$. Together with (6), this implies $s^{*}\left(g^{F B}\right)=s^{F B}$. Hence, the level of general training that maximizes $S(s, g)$ subject to $s=$ $s^{*}(g)$ is equal to $g^{F B}$. The claim $\gamma=1$ follows immediately from (10) and $\Theta\left(s^{F B}, g^{F B}\right)=\emptyset$ which completes the proof. 


\section{References}

Acemoglu, D. (1997), "Training and Innovation in an Imperfect Labor Market," Review of Economic Studies, 64, 445-464.

Acemoglu, D. and J.-S. Pischke (1998), "Why Do Firms Train? Theory and Evidence," Quarterly Journal of Economics 113, 79-119.

Acemoglu, D. and J.-S. Pischke (1999), "The Structure of Wages and Investment in General Training," Journal of Political Economy 107: 539-572. Review of Economic Studies 54, 437-459.

Von Bardeleben, R., Beicht, U. and K. Feher (1995), Betriebliche Kosten und Nutzen der Ausbildung: Repräsentative Ergebnisse aus Industrie, Handel und Handwerk, Berichte zur beruflichen Bildung, Heft 187, Bielefeld: Bertelsmann.

Becker, G. (1964), Human Capital, Chicago: The University of Chicago Press.

Binmore, K. (1987), "Perfect Equilibria in Bargaining Models," in: Binmore, K. and P. Dasgupta (eds.), The Economics of Bargaining, Oxford: Blackwell, 77-105.

Binmore, K., Shaked, A. and J. Sutton (1989), "An Outside Option Experiment," Quarterly Journal of Economics 104, 753-770.

Bishop, J. H. (1991), "On New Hires," in: Stern, D. and J.M. Ritzen (eds.): Market Failure in Training?, Berlin: Springer, 61-91.

Blanchflower, D.G., Oswald, A.J., and P. Sanfey (1996), "Wages, Profits, and RentSharing," Quarterly Journal of Economics 111, 227-251.

Blinder, A.S. and A.B. Krueger (1996), "Labor Turnover in the US and Japan: A Tale of Two Countries," Pacific Economic Review 1, 27-57.

Chang, C. and Y. Wang (1995), "A Framework for Understanding Differences in Labor Turnover and Human Capital Investment," Journal of Economic Behavior and Organization 28, 91-105.

Chiang, S.-H. and S.-C. Chiang (1990), General Human Capital as a Shared Investment under Asymmetric Information, Canadian Journal of Economics 23, 175-188.

Chiu, Y. S. and B. R. Yang (1999), "The outside option, threat point, and Nash Bargaining Solution," Economic Letters 62, 181-188.

Edlin, A. and S. Reichelstein (1996), "Holdups, Standard Breach Remedies, and Optimal Investment," American Economic Review 86, 478-501. 
Franz, W. and D. Soskice (1995), "The German Apprenticeship System," in: F. Buttler et al.: Institutional Frameworks and Labor Market Performance. Comparative Views on the German and U.S. Economies, London: Routledge, 208-234.

Gersbach, H. and A. Schmutzler (2001), A Product Market Theory of Training and Turnover in Firms, mimeo, University of Zürich.

Grossman, S.J. and O. Hart (1986), "The Costs and Benefits of Ownership: A Theory of Vertical and Lateral Integration," Journal of Political Economy 94, 691-719.

Grout, P.A. (1984), "Investment and Wages in the Absence of Binding Contracts," Econometrica 52, 449-460.

Harhoff, D. and T.J. Kane (1997), "Is the German Apprenticeship System a Panacea for the U.S. Labor Market?," Journal of Population Economics 10, 171-196.

Hart, O. and J. Moore (1990), "Property Rights and the Nature of the Firm," Journal of Political Economy 98, 1119-1158.

Hashimoto, M. (1981), "Firm-Specific Human Capital as Shared Investment," American Economic Review 71 (3), 475-482.

Kahn, L.M. and J. K. Murnighan (1993), "A General Experiment on Bargaining in Demand Games with Outside Options," American Economic Review 83 (5), 1260-1280.

Knez, M.J. and C.F. Camerer (1995), "Outside Options and Social Comparison in Three-Player Ultimatum Game Experiments," Games and Economic Behavior, 10, 6594.

Katz, E. and A. Ziderman (1990), "Investment in General Training: The Role of Information and Labor Mobility," Economic Journal 100, 1147-1158.

Loewenstein, M. and J.R. Spletzer (1998), "General and Specific Training: Evidence from the NLSY," mimeo, Bureau of Labor Statistics, Washington.

MacLeod, B. and J. Malcomson (1993a), "Investments, Hold-up, and the Form of Market Contracts," American Economic Review 83, 811-837.

MacLeod, B. and J. Malcomson (1993b), "Specific Investments and Wage Profiles in Labor Markets," European Economic Review 37, 343-354.

MacLeod, B. and J. Malcomson (1995), "Contract Bargaining with Symmetric Information," Canadian Journal of Economics 28, 336-367.

Malcomson, J.M. (1997), "Contracts, Hold-Up, and Labor Markets," Journal of Economic Literature 35, 1916-1957. 
Malcomson, J.M., J.W. Maw, and B. McCormick (1999), "General Training by Firms, Contracts, and Public Policy," mimeo, Universities of Oxford, Swansea Wales, and Southampton.

Osborne, M.J. and A. Rubinstein (1990), Bargaining and Markets, San Diego: Academic Press.

Rosen, S. (1994), "Implicit Contracts: A Survey," in Rosen, S. (ed.) Implicit Contract Theory, U.K: Elgar.

Ryan, P. (1980), "The Costs of Job Training for a Transferable Skill," British Journal of Industrial Relations 18, 334-352.

Scaramozzino, P. (1991), "Bargaining with Outside Options: Wages and Employment in UK Manufacturing 1974-82," Economic Journal 101, 331-342.

Shaked, A. and J. Sutton (1984), "Involuntary Unemployment as a Perfect Equilibrium in a Bargaining Model," Econometrica 52, 1351-1364.

Soskice, D. (1994), "Reconciling Markets and Institutions: The German Apprenticeship System," in: L.M. Lynch (ed.), Training and the Private Sector: International Comparisons, Chicago: University of Chicago Press, NBER conference volume.

Stevens, M. (1994), "A Theoretical Model of On-the-job Training with Imperfect Competition," Oxford Exonomic Papers 46, 537-562.

Topel, R.H. and M.P. Ward (1992), "Job Mobility and the Careers of Young Men," Quarterly Journal of Economics, 107: 439-479.

Williamson, O.E. (1975), Markets and Hierarchies: Analysis and Antitrust Implications, New York: The Free Press.

Yu, Kuo (1999), "Why Do Firms Provide Firm-Sponsored Education?," mimeo, UC Berkeley. 


\section{CESifo Working Paper Series}

(for full list see www.cesifo.de)

705 Daniel Gros and Carsten Hefeker, Common Monetary Policy with Asymmetric Shocks, April 2002

706 Dirk Kiesewetter and Rainer Niemann, Neutral and Equitable Taxation of Pensions as Capital Income, April 2002

707 Robert S. Chirinko, Corporate Taxation, Capital Formation, and the Substitution Elasticity between Labor and Capital, April 2002

708 Frode Meland and Gaute Torsvik, Structural Adjustment and Endogenous Worker Recall Probabilities, April 2002

709 Rainer Niemann and Caren Sureth, Taxation under Uncertainty - Problems of Dynamic Programming and Contingent Claims Analysis in Real Option Theory, April 2002

710 Thomas Moutos and William Scarth, Technical Change and Unemployment: Policy Responses and Distributional Considerations, April 2002

711 Günther Rehme, (Re-)Distribution of Personal Incomes, Education and Economic Performance Across Countries, April 2002

712 Thorvaldur Gylfason and Gylfi Zoega, Inequality and Economic Growth: Do Natural Resources Matter?, April 2002

713 Wolfgang Leininger, Contests over Public Goods: Evolutionary Stability and the FreeRider Problem, April 2002

714 Ernst Fehr and Armin Falk, Psychological Foundations of Incentives, April 2002

715 Giorgio Brunello, Maria Laura Parisi, and Daniela Sonedda, Labor Taxes and Wages: Evidence from Italy, May 2002

716 Marta Aloi and Huw Dixon, Entry Dynamics, Capacity Utilisation and Productivity in a Dynamic Open Economy, May 2002

717 Paolo M. Panteghini, Asymmetric Taxation under Incremental and Sequential Investment, May 2002

718 Ben J. Heijdra, Christian Keuschnigg, and Wilhelm Kohler, Eastern Enlargement of the EU: Jobs, Investment and Welfare in Present Member Countries, May 2002

719 Tapio Palokangas, The Political Economy of Collective Bargaining, May 2002

720 Gilles Saint-Paul, Some Evolutionary Foundations for Price Level Rigidity, May 2002 
721 Giorgio Brunello and Daniela Sonedda, Labor Tax Progressivity, Wage Determination, and the Relative Wage Effect, May 2002

722 Eric van Damme, The Dutch UMTS-Auction, May 2002

723 Paolo M. Panteghini, Endogenous Timing and the Taxation of Discrete Investment Choices, May 2002

724 Achim Wambach, Collusion in Beauty Contests, May 2002

725 Dominique Demougin and Claude Fluet, Preponderance of Evidence, May 2002

726 Gilles Saint-Paul, Growth Effects of Non Proprietary Innovation, May 2002

727 Subir Bose, Gerhard O. Orosel, and Lise Vesterlund, Optimal Pricing and Endogenous Herding, May 2002

728 Erik Leertouwer and Jakob de Haan, How to Use Indicators for 'Corporatism' in Empirical Applications, May 2002

729 Matthias Wrede, Small States, Large Unitary States and Federations, May 2002

730 Christian Schultz, Transparency and Tacit Collusion in a Differentiated Market, May 2002

731 Volker Grossmann, Income Inequality, Voting Over the Size of Public Consumption, and Growth, May 2002

$732 \mathrm{Yu}-\mathrm{Fu}$ Chen and Michael Funke, Working Time and Employment under Uncertainty, May 2002

733 Kjell Erik Lommerud, Odd Rune Straume, and Lars Sørgard, Downstream Merger with Oligopolistic Input Suppliers, May 2002

734 Saku Aura, Does the Balance of Power Within a Family Matter? The Case of the Retirement Equity Act, May 2002

735 Sandro Brusco and Fausto Panunzi, Reallocation of Corporate Resources and Managerial Incentives in Internal Capital Markets, May 2002

736 Stefan Napel and Mika Widgrén, Strategic Power Revisited, May 2002

737 Martin W. Cripps, Godfrey Keller, and Sven Rady, Strategic Experimentation: The Case of Poisson Bandits, May 2002

738 Pierre André Chiappori and Bernard Salanié, Testing Contract Theory: A Survey of Some Recent Work, June 2002

739 Robert J. Gary-Bobo and Sophie Larribeau, A Structural Econometric Model of Price Discrimination in the Mortgage Lending Industry, June 2002 
740 Laurent Linnemer, When Backward Integration by a Dominant Firm Improves Welfare, June 2002

741 Gebhard Kirchgässner and Friedrich Schneider, On the Political Economy of Environmental Policy, June 2002

742 Christian Keuschnigg and Soren Bo Nielsen, Start-ups, Venture Capitalits, and the Capital Gains Tax, June 2002

743 Robert Fenge, Silke Uebelmesser, and Martin Werding, Second-best Properties of Implicit Social Security Taxes: Theory and Evidence, June 2002

744 Wendell Fleming and Jerome Stein, Stochastic Optimal Control, International Finance and Debt, June 2002

745 Gene M. Grossman, The Distribution of Talent and the Pattern and Consequences of International Trade, June 2002

746 Oleksiy Ivaschenko, Growth and Inequality: Evidence from Transitional Economies, June 2002

747 Burkhard Heer, Should Unemployment Benefits be Related to Previous Earnings?, July 2002

748 Bas van Aarle, Giovanni Di Bartolomeo, Jacob Engwerda, and Joseph Plasmans, Staying Together or Breaking Apart: Policy-makers' Endogenous Coalitions Formation in the European Economic and Monetary Union, July 2002

749 Hans Gersbach, Democratic Mechanisms: Double Majority Rules and Flexible Agenda Costs, July 2002

750 Bruno S. Frey and Stephan Meier, Pro-Social Behavior, Reciprocity or Both?, July 2002

751 Jonas Agell and Helge Bennmarker, Wage Policy and Endogenous Wage Rigidity: A Representative View From the Inside, July 2002

752 Edward Castronova, On Virtual Economies, July 2002

753 Rebecca M. Blank, U.S. Welfare Reform: What's Relevant for Europe?, July 2002

754 Ruslan Lukach and Joseph Plasmans, Measuring Knowledge Spillovers Using Patent Citations: Evidence from the Belgian Firm's Data, July 2002

755 Aaron Tornell and Frank Westermann, Boom-Bust Cycles in Middle Income Countries: Facts and Explanation, July 2002

756 Jan K. Brueckner, Internalization of Airport Congestion: A Network Analysis, July 2002

757 Lawrence M. Kahn, The Impact of Wage-Setting Institutions on the Incidence of Public Employment in the OECD: 1960-98, July 2002

758 Sijbren Cnossen, Tax Policy in the European Union, August 2002 
759 Chandima Mendis, External Shocks and Banking Crises in Developing Countries: Does the Exchange Rate Regime Matter?, August 2002

760 Bruno S. Frey and Lars P. Feld, Deterrence and Morale in Taxation: An Empirical Analysis, August 2002

761 Lars Calmfors and Åsa Johansson, Nominal Wage Flexibility, Wage Indexation and Monetary Union, August 2002

762 Alexander R. W. Robson and Stergios Skaperdas, Costly Enforcement of Property Rights and the Coase Theorem, August 2002

763 Horst Raff, Preferential Trade Agreements and Tax Competition for Foreign Direct Investment, August 2002

764 Alex Cukierman and V. Anton Muscatelli, Do Central Banks have Precautionary Demands for Expansions and for Price Stability? - Theory and Evidence, August 2002

765 Giovanni Peri, Knowledge Flows and Knowledge Externalities, August 2002

766 Daniel Friedman and Nirvikar Singh, Equilibrium Vengeance, August 2002

767 Sam Bucovetsky and Michael Smart, The Efficiency Consequences of Local Revenue Equalization: Tax Competition and Tax Distortions, August 2002

768 Tapio Palokangas, International Labour Market Regulation and Economic Growth with Creative Destruction, August 2002

769 Rudi Dornbusch, The New International Architecture, September 2002

770 Hans-Werner Sinn, Weber's Law and the Biological Evolution of Risk Preferences: The Selective Dominance of the Logarithmic Utility Function, September 2002

771 Thomas Mayer, The Macroeconomic Loss Function: A Critical Note, September 2002

772 Seppo Honkapohja and Kaushik Mitra, Learning Stability in Economies with Heterogenous Agents, September 2002

773 David Laidler, Inflation Targets Versus International Monetary Integration - A Canadian Perspective, September 2002

774 Morten I. Lau, Panu Poutvaara, and Andreas Wagener, The Dynamic Cost of the Draft, September 2002

775 Steven Brakman, Harry Garretsen, and Charles van Marrewijk, Locational Competition and Agglomeration: The Role of Government Spending, September 2002

776 Anke S. Kessler and Christoph Lülfesmann, The Theory of Human Capital Revisited: On the Interaction of General and Specific Investments, September 2002 